\title{
AJARAN SIWA-BUDDHA DALAM LONTAR CANDRA BHERAWA PERSPEKTIF PENDIDIKAN AGAMA HINDU
}

\author{
Oleh: \\ I Nyoman Ariyoga \\ Jurusan Pendidikan Agama Hindu \\ Program Pasca Sarjana \\ Universitas Hindu Indonesia, Denpasar \\ ariyoganyoman@yahoo.com
}

\begin{abstract}
Lontar is a classic literary work that has very high values of Hindu religious education. But unfortunately most Balinese people simply consider lontar as a sacred heritage and should not be just studied that just kept and diupacarai in certain holy-heri day. One of the Hindu heritage of Lontar Parwa is Lontar Candra Bherawa. This book has a planting of concepts, planting understanding or definition and planting of different religious teachings in the fabric of events. Besides this, it also reinforces and gives a deep impression on the readers and listeners about the benefits gained from the teachings of Siwa-Buddha. Not only in this context, the readers and listeners will be invited to enter the prismatic path, which is a plot where readers and listeners themselves will find wisdom through jujaran image or characters displayed from each of the figures of maharaja Yudhisthira and Chess Pandawa and figures Maharaja Candra Bherawa. Therefore, how important and special is Lontar Candra Bherawa this.
\end{abstract}

Keywords : : Siwa-Buddha, Candra Bherawa, Hindu religious education

\begin{abstract}
ABSTRAK
Lontar merupakan karya sastra klasik yang memiliki nilai-nilai pendidikan agama Hindu yang sangat tinggi. Namun sayangnya masyarakat Bali kebanyakan hanya menganggap lontar sebagai warisan yang disakralkan dan tidak boleh sembarang dipelajari yang hanya disimpan dan diupacarai di hari-heri suci tertentu. Salah satu warisan agama Hindu berupa Lontar Parwa adalah Lontar Candra Bherawa. Kitab ini memiliki penanaman konsep, penanaman pengertian atau difinisi dan penanaman akan ajaran agama yang berbeda dalam jalinan peristiwa. Disamping hal tersebut, juga mempertegas dan memberikan kesan mendalam pada pembaca dan pendengar tentang manfaat yang didapatkan dari ajaran Siwa-Buddha. Bukan dalam konteks ini saja, pembaca dan pendengar akan diajak untuk masuk dalam alur prismatis yakni sebuah alur dimana pembaca dan pendengar sendiri yang akan menemukan kebijaksanaan lewat jabaran citra atau karakter yang ditampilkan dari setiap tokoh maharaja Yudistira dan Catur Pandawa serta tokoh maharaja Candra Bherawa. Oleh sebab itu, betapa penting dan istimewanya Lontar Candra Bherawa ini.
\end{abstract}

Kata Kunci : Siwa-Buddha, Candra Bherawa, Pendidikan Agama Hindu 


\section{PENDAHULUAN}

\subsection{Latar Belakang Masalah}

Pembabakan sejarah

Indonesia maka perkembangan Buddha di Indonesia masuk ke dalam masa klasik berlangsung dari abad 4-16 masehi. Perkembangan agama Hindu di nusantara dari kerjaan Kutai di Kalimantan Timur, di Jawa Barat mulai abad ke-5, yaitu kerajaan Tarumanegara, selanjutnya agama Hindu berkembang di Jawa Tengah, Jawa Timur hingga sampai di kerajaan Majapahit. Sebelum agama Hindu masuk ke Bali, penduduk Bali sudah memiliki sistem peradaban dan kepercayaan. Diantaranya mempercayai roh nenek moyang bisa memberikan perlindungan, Pada abad ke-8 setelah masuknya agama Hindu dan Buddha di Bali mengalami perkembangan sosio-religius sangat tinggi, sehingga mencapai puncak kesempurnaan, jaman kerajaan Dalem Waturenggong. Banyak karya sastra kuno di muat dalam lontar.

Salah satu warisan agama Hindu berupa Lontar Parwa adalah Lontar Candra Bherawa adalah suatu karya sastra yang tergolong klasik memiliki banyak pengetahuan ajaran-ajaran Agama Hindu, baik dalam bentuk ajaran tattwa, susila, maupun juga upacara yang masih sangat relevan diimplementasikan dalam kehidupan masyarakat. Selain itu Lontar Candra Bherawa memberikan kontribusi cerita mengenai konsep ketuhanan Siwa-Buddha yang menjadi momentum bersatunya kedua paham ajaran ini, yang pernah menjadi sebuah konsep kepercaaan agama di bumi Nusantara Indnesia.

Perbedaan paham Siwa dan Buddha dalam Lontar Candra Bherawa menjadikan konflik diantara masing-masing penganut paham tersebut. Satu sisi tokoh dari maharaja Yudistira dan Catur Pandawa adalah pemuja Sang Hyang Siwa yang sangat teguh. Sedangkan dari tokoh maharaja Candra Bherawa adalah pemuja Sang Hyang Adi Buddha yang sangat teguh. Pada akhirnya terjadilah peperangan dalam menunjukan keteguhan dharma.

Bijaksana, kuat dan teguh, pantang menyerah, penuh pengetahuan, dan tidak sabaran, serta yang lainnya semuanya terwakili dalam setiap karakterisasi maharaja Yudistira, Catur Pandawa dan maharaja Candra Bherawa. Saling menunjukan keteguhan dharma yang pegang dan dipercayai. Membuktikan bahwa untuk mendapatkan sebuah kebenaran harus dilakukan dengan cara pembuktian melalui usaha-usaha yang bisa diterima oleh orang banyak. bahwa hakekatnya ajaran Siwa dan Buddha itu saling melengapi satu sama lain. Tidak sempurnalah jika seseorang hanya teguh menjalankan ajaran Siwa melalui Karma Sanyasa, begitu pula sebaliknya tidaklah sempurna bila seseorang hanya teguh menjalankan ajaran Buddha melalui Yoga Sanyasa. Kesatuan konsep ajaran Siwa-Buddha tidak dapat terpisahkan seperti yang di perlihatkan dalam narasi Lontar Candra Bherawa.

Citra-citra dari setiap tokoh ini dipergunakan oleh rakawi tanah Bali, untuk mewakili ajaran serta pendidikan Agama Hindu. Jadi pendidikan yang dimaksudkan dalam penelitian ini adalah sebuah proses pendewasaan manusia mengenai pola pikir, perkataan hingga tingkah lakunya, yang kemudian menimbulkan sebuah kesadaran akan jati diri dan menumbuh kembangan sebuah kebijaksanaan akan afeksi moralitas dan kesadaran akan Tuhan Yang Maha Esa. Dalam hal ini, ada sebuah penguatan mengenai keutamaan dharma yang diperoleh. Jika kita hubungkan dengan pendidikan itu sendiri, bahwa hakikat pendidikan itu menjadi orang lebih bijaksana, penguatan moralitas, etika dan budi pekerti luhur.

Metode yang digunakan dalam penerapan pendidikan yang terkandung dalam Lontar Candra Bherawa adalah metode demontrasi. Untuk menyatakan isi cerita Lontar Candra Bherawa, maharaja Candra Bherawa dan maharaja Yudistira menjadikan diri sendiri sebagai contoh dan tauladan dalam menjalankan serta mengajarkan ilmu ketaatan, kedisiplinan, Sradha dan Bhakti kepada rakyatnya yang ditujukan kehadapan Tuhan. Dalam hal ini menekankan sikap Yoga Sanyasa dan Karma sanyasa.

Berdasarkan hal tersebut di atas, pemilihan Lontar Candra Bherawa sebagai objek penelitian adalah suatu usaha untuk inventaris, menerjemahkan, menganalisis, mensosialisasikan ajaranya dalam kehidupan beragama. sehingga dapat diimplementasikan nilai-nilai pendidikan Agama Hindu yang terkandung di dalamnya. Untuk dapat diterapkan dikalangan masyarakat ali khususnya dan umat Hindu pada umumnya, sehingga dengan pengkajian Lontar Candra Bherawa, mampu mengetahui bagaimana struktur, konsep-konsep Siwa-Buddha yang dijarkan, dan manfaat didaktis pembelajaran konsep-konsep Siwa-Buddha yang tertuang secara tekstual dalam 
Lontar Candra Bherawa.

\subsection{Teori}

Teori merupakan seperangkat konsep, proposisi, yang telah diuji kebenaranya dan berguna untuk memecahkan masalah atau fenomena yang akan diteliti. Dalam penelitian ini, teori yang digunakan yaitu (1) Teori Struktural, (2) Teori Hermeneutik dan (3) Teori Kontruktivistik.

Teori Struktural adalah suatu disiplin memandang karya sastra sebagai suatu struktur yang terdiri atas beberapa unsur yang saling berkaitan antara yang satu dengan yang lainya. Analisis struktural sastra disebut juga pendekatan objektif dan menganalisis unsur intrinsiknya. Fananie (2002:112) mengemukakan bahwa pendekatan objektif adalah pendekatan yang mendasarkan pada suatu karya sastra secara keseluruhan. Pendekatan yang dinilai dari eksistensi sastra itu sendiri berdasarkan konvensi sastra yang berlaku.

Secara etimologis hermeneutik berasal dari kata "hermeneuein", bahasa Yunani, yang berarti "menafsirkan atau menginterpretasikan". Menurut Kutha (2009:45) menyatakan Karya sastra perlu ditafsirkan karana disatu pihak karya sastra terdiri atas bahasa, dipihak lain dalam bahasa banyak makna yang tersembunyi atau dengan sengaja disembunyikan.

Teori konstruktivistik adalah memahami belajar sebagai proses pembentukan (konstruksi) pengetahuan oleh si pelajar itu sendiri. Putrayasa (2011:22-23) menyatakan bahwa belajar menurut pandangan konstruktivistik lebih diarahkan pada terbentuknya makna pada diri pembelajar atas apa yang dipelajarinya berdasarkan pengetahuan dan pemahaman mereka sebelumnya.

\subsection{Metode Penelitian}

Penelitian ini merupakan penelitian tekstual, yakni menggunakan teks sebagai sumber utama. Hal ini dilakukan semata untuk mengetahui pola pikir dan kronologis pemikiran umat Hindu pada masa silam. Demikian pula, jenis penelitian ini adalah jenis penelitian deskriptif dengan menggunakan pendekatan penelitian kualitatif.

Pada mulanya teks ini berupa sebuah cakapan lontar, kemudian oleh Dinas Kebudayaan Provinsi Bali mengupayakan untuk dialih aksarakan. Penelitian ini berpedoman pada cakapan lontar dan hasil alih aksara yang telah diterbitkan oleh Dinas Kebudayaan Provinsi Bali. Penelitian ini adalah penelitian kualitatif, oleh karena penelitian yang digunakan tidak berfokus pada suatu tempat, tetapi mengunakan penelitian dokumen perpustakaan, buku-buku yang ada kaitanya dengan materi penelitian.

Dalam penelitian ini metode studi dokumen dilakukan dengan mempelajari, meneliti, dan mencatat data-data penting dalam Lontar Candra Bherawa, serta dokumen-dokumen lain yang berkaitan dengan penelitan ini.

Wawancara yang digunakan dalam penelitian ini adalah tehnik purposive sampling. Purposive sampling adalah teknik pengambilan sampel sumber data dengan pertimbangan tertentu. Pertimbanggan tertentu ini, misalnya orang tersebut sudah memiliki usia yang cukup, pendidikan yang memadai, wawasan dan pengalaman yang luas serta mereka dianggap mengetahui tentang apa yang diteliti.

Setelah data diperoleh dan terkumpul, langkah selanjutnya data diolah dan dianalisa. Pertama, aktualisasi dari langkah kerja penelitian deskriptif dengan menggunakan pendekatan penelitian kualitatif. Kedua, langkah selanjutnya ialah naskah terpilih, teksnya kemudian dibaca berulang-ulang dengan tujuan untuk memberikan penghayatan serta pemberian gambaran peneliti. Ketiga, pembacaan secara struktural tersebut di atas, dipandang mempemudah kearah pelacakan intertekstualitas. Dalam rangka mendapatkan makna kata-kata terpilih, ungkapan tertentu yang khas dan jalan cerita dalam Lontar Candra Bherawa secara oprasional ungkapan yang di pandang sarat makna dikaji dengan menerapkan metodenya teori hermeneutik. Pengetahuan yang didapatkan dari kalimat-kalimat yang sudah di tapsirkan maknanya akan memberikan asumsi baru dalam pikiran. Ini dapat di ungkap dengan metodenya teori kontruktivistik.

\section{PEMBAHASAN}

\subsection{Struktur Teks dalam Lontar Candra Bherawa}

Struktur cerita Candra Bherawa terdiri dari: 1). Teks dalam Lontar Candra Bherawa menceritakan Maharaja Yudhistira penganut paham Kasiwan dan Maharaja Candra Bherawa penganut paham Kasogatan. Menjadi ujung penyelesaian cerita tersebut adanya penyatuan kedua ajaran menjadi konsep Siwa-Buddha. 2). Latar yang terdapat adalah latar fisik dan latar sosial. Latar fisik yang dianalisis berdasarkan latar tempat dan waktu. Latar tempat di Hastinapura, Dewantara, Alama Niskala. Latar 
waktu, terjadi jalanya cerita pada pagi sampai sore hari. Sedangkan latar sosilanya merupakan upacara pernikahan Raja Yudhistira dengan Dyah Ratna Sasangka. 3). Penokohan terdiri dari tokoh utama adalah Maharaja Candra Bherawa, Maharaja Kresna, dan Maharaja Yudhistira. Tokoh sekunder adalah Sang Bhima, dan tokoh komplementer adalah Sang Panca Pandawa, Sang Brahma, Sang Wisnu, patih kiratha, patih Witarga, patih Mangkubhumi, patih Dewantaka, dan dewa Siwa, Dyah Ratna Sasangka yang masing-masing penokohan dianalisis berdasarkan keadaan fisik, sosiologis, dan psikologis. 4). Insiden dalam Lontar Candra Bherawa terdiri dari 9 Insiden yang berjalan secara wajar dan logis sehingga memberi kesan jika kisah tersebut benar-benar terjadi. 5). Alur cerita memakai alur lurus, karena cerita tersebut disusun mulai dari kejadian awal diteruskan dengan kejadiankejadian berikutnya dan berakhir pada pemecahan masalah. 6). Tema dalam Lontar Candra Bherawa adalah sebuah "pendidikan Spiritual" mengenai penyatuan paham "Siwa-Buddha". 7). Amanat dalam Lontar Candra Bherawa amanat yang disampaikan menjelaskan stratafikasi sosial dari Catur Warna. Serta Maharaja Candra Bherawa dan Maharaja Yudhistira mengumandangkan untuk selalu menjalankan ajaran agama melalui pelaksanaan Yoga sanyasa dan Karma Sanyasa.

\subsection{Konsep-Konsep Ajaran Siwa-Buddha dalam Lontar Candra Bherawa \\ 1). Konsep Catur Warna}

Catur warna yaitu menguraikan tentang pemahaman stratafikasi manusia berdasarkan profesi yang terdiri dari Brahmana, Ksatrya, Vaisya, dan Sudra. Dalam isi cerita Lontar Candra Bherawa terdapat dua anggapan yang berbeda, pada wilayah kerajaan Hastinapura Catur Warna sangat diakui dan dijalani oleh setiap individu berdasarkan profesi yang dijalani mereka dalam kehidupan. Sedangkan di kerajaan Dewantara konsep Catur Warna diakui berdasarkan di setiap individu ke empat warna tersebut sudah tertanam, baik Brahmana, Ksatrya, Vaisya,dan Sudra semua itu adalah satu dalam setiap individu. Tidak ada yang membedakan invidu satu dengan yang lainya yang berdasarkan Catur Warna, semuanya sama.

\section{2). Karma Sanyasa}

Konsep Karma Sanyasa yaitu pembebasan diri dari ikatan kerja. Menurut Lontar Candra Bherawa ajaran Karma Sanyasa bersumber dari sebuah lontar yang disebut Purwa Dharma Sasana. Sasana atau etika yang dijadikan pedoman ajaran Tri Kaya Parisudha yaitu tiga gerak yang harus disucikan. Tiga gerak yang dimaksud antara lain : (1) gerak pikiran yang baik dan suci disebut Manacika Parisudha, (2) gerak perkataan yang baik, benar dan suci disebut Wacika Parisudha, (3) gerak tingkah laku yang baik dan suci disebut Kayika Parisudha. Bila ketiga gerak itu baik dan dapat dilaksanakan dengan serasi, seeseorang telah termasuk melaksanakan ajaran susila. Setelah umat dapat melaksanakan ajaran Tri Kaya Parisudha menurut Lontar Candra Bherawa yang melaksanakan ajaran Karma Sanyasa ia patut membangun tempat suci dalam lingkungan keluarga pada pekarangan sendiri yang disebut Sanggar Dengen dan Sanggar Kabuyutan. Setelah mempunyai Sanggar Dengen dan Sanggar Kabuyutan, antara rakyat dan raja patut membangun Sad Kahyanngan di suatu wilayah negara sebagi bukti kepada Tuhan dan segala manifestasinya. Ajaran Karma Sanyasa merupakan sadhana pendakian spiritual dari paham Kasiwan (Siwa).

\section{3). Yoga Sanyasa}

Konsep Yoga Sanyasa yaitu cara menghubungkan diri dengan Tuhan tanpa ikatan jasmani dan rohani, tetap dalam renungan mendalam dalam diri. Kerajaan Dewantara menganut paham agama yang disebut Aji Pegat, yaitu pengetahuan suci pemutus. Pemutus yang dimaksud dalam Lontar Candra Bherawa adalah memutuskan unsur-unsur duniawi dalam melaksanakan ajaran agama. Sehingga tidak perlu lagi membuat tempat suci, tidak perlu lagi membuat banten, tidak perlu lagi melaksanakan upacara mecaru, tidak lagi terikat pada hal-hal yang bersifat duniawi. Tetapi mereka berpegang teguh pada ajaran moralitas yang berlandaskan ajaran Dharma. Menjadikan diri sebagai manusia sakti yaitu orang yang mampu menguasai indriyanya, atau orang yang sudah dapat menguasai indriyanya, sehingga pikiran, perkataan dan perbuatannya sesuai dengan suara hati nuraninya yaitu kebenaran (Dharma). Ajaran Yoga Sanyasa merupakan sadhana pendakian spiritual dari paham Kasogatan (Buddha).

\section{4). Konsep Dharma dan Satya}

Dharma berasal dari urat kata $d h r$ yang mengandung arti kebajikan, kesucian, kebenaran, kewajiban, hukum. Satya artinya yaitu kebenaran, 
kejujuran, dalam pikiran, perkataan dan perbuatan. Satya adalah Dharma yang tertinggi. Dalam cerita Lontar Candra Bherawa adapun perbedaan yang menjadi titik puncak peperangan yang terjadi karena adanya dua prinsip Dharma yang berbeda. Disatu sisi sosok Maharaja Yudhistira sebagai penganut paham Siwa yang tertu berbeda pelaksanaan sadhana pendakian spiritaulnya dengan penganut ajaran Buddha dari sosok Maharaja Candra Bherawa. Dari kedua cara dan definisi yang berbeda ini dalam mempertahankan Dharma junjunganya, dengan diimbangi dengan sikap satya maka terjadilah perang untuk menunjukan keagungan Dharma yang tertinggi.

\section{Konsep Aji Bhuwana Sarira}

Kata Aji dalam bahasa jawa kuno artinya ilmu pengetahuan, Bhuwana dalam bahasa Sansekerta mengandung arti alam, dan sarira berasal dari bahasa Sansekerta tergolong jenis kata benda netrum, yang artinya tubuh atau badan. (Samadi Astra, 1984:242). Aji Bhuwana Sarira artinya ilmu pengetahuan tentang alam, alam yang dimaksud dalam konteks ini adalah alam raya atau alam semesta, dalam bahasa agama disebut Bhuwana Agung, dan Bhuwana Alit. Dalam dunia ilmiah, Bhuwana Agung dan Bhuwana Alit sering disebut Macrocosmos dan Microcosmos. Menstarakan anatara alam raya macrocosmos dan alam kecil tubuh manusia atau Microcosmos adalah ciri khas dari ajaran Agama Hindu yang bersifat logis dan ilmiah. Konsep kerahayuan dapat tercapai apabila terjadi keseimbangan antara Bhuwana Agung dan Bhuwana Alit. Sehingga antara alam semesta dan manusia perlu saling mengasihi, saling melindungi dan saling memberi. Konsep Aji Bhuwana Sarira merupakan pengetahuan tentang alam raya dalam tubuh manusia seperti dalam Lontar Candra Bherawa terdiri dari: Sapta Patala, Sapta Bhuwana, Sapta Parwata, Sapta Sagara, Saptagni, Sapta Sunya, pengetahuan tentang Dasa Bayu dan berbagai jenis nadi.

\section{6). Konsep Sinkretisme Siwa-Buddha}

Sinkretisme adalah upaya untuk
menenggelamkan berbagai perbedaan dan menghasilkan kesatuan di antara berbagai sekte atau aliran filsafat. (Diartha Nida, 2003:17). Siwa-Buddha adalah sebuah konsep kesatuan antara dua paham kepercayaan yang berbeda, yang lebur menjadi satu saling melengkapi satu dengan yang lainya. Sehingga menjadi agama yang sempurna bila dijalani dengan penuh disiplin oleh umatnya. inti pokok ajaran Siwa-Buddha itu adalah nirbana atau nissreyasa, bersatu dengan Paramartha Siwa Buddha. Orang yang telah mencapai nissreyasa tidaklah mempermasalahkan apakah melaksanakan puja atau yoga, juga tidak menghendaki kemegahan dunia. Lepas dari pengaruh duniawi, hidup mati tidak jadi halangan. Karena seakan-akan berbadan Tuhan telah mencapai nirbana. Tetapi tidak berlaku yang belum mencapai nirbana atau nissreyasa, yang belum mencapai harus giat mengusahakan diri agar mencapai nirbana dengan disiplin yang diajarkan Sang Buddha dan Siwa.

\subsection{Manfaat Didaktis Pembelajaran Konsep- Konsep Siwa-Buddha dalam Lontar Candra Bherawa}

\section{1). Manfaat Didaktis Religius}

Lontar Candra Bherawa secara religius adalah paham Siwa dan Buddha. Oleh pengarang konsepsikonsepsi ajaran Siwa dan Buddha yang dijalani dalam suatu cerita yang sangat menarik lewat kaya sastra berupa lontar. Melalui tokoh-tokoh dalam cerita pengarang menyampaikan ajaran Siwa dan Buddha. Tokoh Kresna, Dharmawangsa, Candra Bherawa merupakan tokoh penting yang masingmasing ingin mperlihatkan keunggulan dalam mencapai tujuan. Melaui dioalog para tokoh dalam Lontar Candra Bherawa, pengarang menyampaikan maksud kepada pembaca, betapa hebatnya tokoh Dharmawangsa, Kresna, dan Candra Bherawa. Saling memperlihatkan kesaktian untuk mencapai tujuan masing-masing. Dalam fragmen tersebut terdapatlah nilai-nilai religius filosofis seperti sifat pengendalian diri, cinta kasih, dan iklas berkorban.

\section{2). Manfaat Didaktis Etika}

Manfaat Didaktis Etika dalam Lontar Candra Bherawa ialah Maharaja Yudhistira adalah tokoh raja yang sudah tercerahkan mencapai kesempurnaan lahir dan batin dengan melaksanakan ajaran Tri Kaya Parisudha dengan melaksanakan pendekatan Karma Sanyasa yang diajarkan di wilayah kerajaan dengan harapan rakyatnya di kerajaan Hastinapura ikut mencapai kesempurnaan dengan melaksanakan ajaran Tri Kaya Parisudha yang menekankan pada pelaksanaan etika dan moralitas. Maharaja Candra Bherawa sebagai penanut paham Buddha beserta rakyatnya di Dewantara, tercerahkan dengan melaksanakan konsep ajaran Catur Paramitha serta Jalan Mulia Berunsur Delapan. Dengan menekankan pada ajaran etika dan moralitas, kesadaran, 
kebijaksanaan, dan kesempurnaan dapat tercapai dalam hidup.

\section{3). Manfaat Didaktis Estetika}

Bila ditelusuri secara seksama tidak terlepas dari nilai estetika yang tersirat didalamnya terutama menyangkut estetika dalam melukiskan suasana alam. Lukisan alam itu diceritakan ketika Sang Bhima yang diutus oleh Maharaja Kresna dan Yudhistira untuk mengawasi desa-desa yang belum melaksanakan ajaran Dharma dalam aktualisasi Karma Sanyasa. Perjalanan yang dilakukan oleh Sang Bhima sangatlah jauh, namun betapa senangnya dan takjubnya melihat pemandangan yang sangat asri, indah, mempesonakan mata. Sehingga perjalanan yang jauh tersebut tidak terasa jauh, disebabkan oleh keindahan pemandangan alam yang memanjakan setiap penglihatan mata, semangatpun akan bangkit, timbuhlah rasa girang dalam diri Sang Bhima. Selain itu cara berkesenian dalam mengetahui isi Lontar Candra Bherawa melalui kelompok-kelompok pesantian yang senantiasa menjadi spirit dalam menjaga dan melestarikan warisan leluhur melalui membaca warisan karya sastra tersebut. Disinilah terdapat unsur seni sebuah karya sastra dalam Lontar Candra Bherawa, melalui bahasa yang digunakan, cara melantunkan penggalan kata, dan cara untuk mengartikan setiap pengalan kata atau kalimat yang dilagukan oleh pembaca. Memberikan nuansa magis yang mampu membangunkan bulu kuduk pembaca dan pendengar bila dilakukan dengan penuh keseriusan.

\section{4). Manfaat Didaktis Sosial}

Bentuk karya sastra yang fantastis dan mistis besar perhatianya terhadap fenomena sosial. Sebagaimana Endawarsa (2013:78) menyatakan bahwa karya sastra boleh dikataan akan tetap menampilkan kejadian-kejaidan yang ada di masyarakat. Manfaat didaktis sosial dalam Lontar Candra Bherawa terletak pada cara seorang raja yang memberikan penuangan, penanaman, bimbingan mengenai ajaran-ajaran Dharma yang harus senantiasa dikumandangkan. Ini secara tidak langsung telah terjadi sebuah proses pendidikan dalam suasana kerajaan dari seorang raja sebagai pendidik dan rakyat kerajaan sebagai peserta didik. Upaya dalam menyatukan dua konsep ajaran Dharma yang berbeda dalam pendekatan Karma Sanyasa dan Yoga Sanyasa dilakukan dengan upacara pernikahan sebagai tanda persatuan ajaran tersebut. Dari upacara tersebut nampak tradisi-tradisi yang bersifat sakral masih dijaga dan kewajiban orang tua kepada anaknya telah dilakukan untuk menikahkan anak dengan pilihan hidupnya. Sebagai harapan untuk memberikan restu dan doa kepada anak, semoga hidupnya mampu menjalankan roda Dharma dan memiliki keturunan yang suputra.

\section{PENUTUP}

\subsection{Kesimpulan}

Struktur cerita Candra Bherawa terdiri dari: 1). Teks dalam Lontar Candra Bherawa menceritakan Maharaja Yudhistira penganut paham Kasiwan dan Maharaja Candra Bherawa penganut paham Kasogatan. 2). Latar, 3). Penokohan, 4). Insiden 5). Alur, 6). Tema, dan 7). Amanat

Konsep-konsep ajaran Siwa-Buddha dalam Lontar Candra Bherawa, terdiri dari: 1). Konsep Catur Warna, 2). Konsep Karma Sanyasa, 3). Konsep Yoga Sanyasa, 4). Konsep Dharma dan Satya, 5). Konsep Aji Bhuwana Sarira, dan 6). Konsep Sinkretisme Siwa-Buddha

Manfaat didaktis pembelajaran konsep-konsep Siwa-Buddha dalam Lontar Candra Bherawa terdiri dari: 1). Manfaat Didaktis Religius, 2). Manfaat Didaktis Etika, 3). Manfaat Didaktis Estetika, dan 4). Manfaat Didaktis Sosial

\subsection{Saran}

Bertitik tolak dari kesimpulan, diajukan beberapa saran yang diajukan kepada pihak-pihak berikut.

Bagi generasi muda Hindu, diharapkan dapat dijadikan bahan referensi dan ikut ambil bagian memperdalam sastra-sastra khususnya Lontar sehingga mampu memahami ajaran yang termuat di dalamnya.

Bagi peneliti selanjutnya, diharapkan dapat melanjutkan penelitian tentang hal-hal yang belum dikaji dalam penelitian ini, sehingga dapat lebih disempurnakan mengingat sangat banyaknya nilainilai yang terkandung dalam Lontar Candra Bherawa.

Bagi lembaga dan pendidik agama Hindu, nilai-nilai pendidikan dalam teks Lontar supaya dapat dijadikan bahan ajar dan kajian khususnya untuk meningkatkan pengetahuan terhadap nilai-nilai pendidikan yang terkandung didalamnya. 


\section{DAFTAR PUSTAKA}

Alih Aksara. 1998. Lontar Candra Bherawa. Denpasar: Pusat Dokumentasi Kebudayaan Bali. Ardika, I Wayan dkk. 2013. Sejarah Bali Dari Prasejarah Hingga Modern. Denpasar: Udayana University Press

Diartha Nida.2003. Sinkretisme Siwa-Buddha di Bali. Denpasar: Bali Post.

Endraswara, Suwardi . 2013. Metodelogi Penelitian Sastra (Edisi Revisi). Yogyakarta: Medpress.

Fananie, Zainuddin.2002. Telaah Sastra. Surakarta: Muhammadiyah University Press.

Mardiwarsito, L. 1986. Kamus Jawa Kuna Indonesia. NTT: Nusa Indah.

Moleong, Lexi J. 2007. Metode Penelitian Kualitatif. Bandung: Remaja Rosdakarya.

Ratna, I Nyoman Kutha. 2011. Teori, Metode dan Teknik Penelitian Sastra dari Strukturalisme hingga Postrukturalisme: Perspektif Wacana Naratif. Yogyakarta: Pustaka Pelajar.

Rema, I Nyoman. 2011. Penyatuan Siwa-Buddha Pemikiran I Gusti Bagus Sugriwa Tentang Agama Hindu Di Bali. Denpasar: IHDN Denpasar

Suamba, Putu, I.B. 2009. Siwa-Buddha Di Indonesia, Ajaran Dan Perkembangannya. Denpasar: PT. Mahabhakti

Sumaryono, E.1999.Hermeneutik. Yogyakarta: Kanisius

Teeuw. 1984. Sastra dan Ilmu Sastra: Pengantar Teori Sastra. Jakarta: PT. Dunia Pustaka Jaya.

Tim Penerjemah. 2004. Tutur Candra Bherawa. Denpasar: Dinas Kebudayaan Provinsi Bali

Zoetmulder, P.J. 1985. Kalangwan Sastra Jawa Kuno Selayang Pandang. Jakarta:Djambatan. 